\title{
KIT/stem cell factor expression in premalignant and malignant lesions of the colon mucosa in relationship to disease progression and outcomes
}

\author{
GRAZIELLA BELLONE $^{1}$, CARLO SMIRNE $^{1}$, ANNA CARBONE ${ }^{2}$, ALESSANDRA BUFFOLINO $^{1}$, \\ TIZIANA SCIRELLI ${ }^{1}$, ADRIANA PRATI ${ }^{1}$, DINO SOLERIO ${ }^{1}$, MARIO PIRISI $^{3}$, \\ GUIDO VALENTE $^{3}$, MARIO NANO ${ }^{1}$ and GIORGIO EMANUELLI ${ }^{1,2}$ \\ ${ }^{1}$ Department of Clinical Physiopathology, University of Turin; ${ }^{2}$ Department of Gastroenterology and Clinical Nutrition, \\ S. Giovanni Battista Hospital, Turin; ${ }^{3}$ Department of Medical Sciences, University of Eastern Piedmont, Novara, Italy
}

Received March 13, 2006; Accepted May 8, 2006

\begin{abstract}
Autocrine/paracrine stimulation of KIT has been observed in colorectal carcinoma (CRC) cell lines. We investigated the expression of KIT and stem cell factor (SCF) in CRC in comparison with premalignant colon lesions and normal colonic mucosa to assess the prognostic and therapeutic relevance of this receptor/ligand system in CRC. Transcript levels of $c$-kit and the two SCF splicing variants were determined quantitatively by real-time RT-PCR using cDNA obtained from normal, premalignant and malignant snap frozen colon tissue specimens. Immunohistochemistry with specific anti-KIT and anti-SCF antibodies was performed on paraffin-embedded tissue sections in order to localize the relative protein expression in epithelial compartments. Approximately $10 \%$ of patients expressed KIT in their adenoma or primary tumor. The majority of KIT-positive carcinomas co-expressed SCF. Real-time RT-PCR showed expression of $c$-kit and SCF transcripts in all cDNA specimens examined. A significant association between the co-expression of KIT/SCF and a worse clinical outcome was found. In conclusion, KIT expression was observed in a proportion of premalignant and malignant colonic lesions, while it was virtually absent in normal colon mucosa. Moreover, the majority of KIT-positive carcinomas co-expressed SCF, suggesting the possibility of aberrant signaling by an autocrine loop, as confirmed by the negative prognostic value of this association. Therefore, in the subset of CRC patients with concomitant KIT/SCF expression, the activity of Imatinib mesylate, a selective
\end{abstract}

Correspondence to: Dr Graziella Bellone, Department of Clinical Physiopathology, Via Genova 3, I-10126 Torino, Italy

E-mail: graziella.bellone@unito.it

Key words: stem cell factor, c-kit, colon carcinoma, adenoma, tyrosine inhibitors, Imatinib mesylate inhibitor of specific tyrosine kinases including KIT, may be exploited in combination with standard therapy.

\section{Introduction}

Neoplastic conversion of human colorectal cells occurs in a stepwise fashion, from benign lesions to clinically-aggressive tumors. Tumor progression in this system, as defined by clinical and histopathological criteria, has been correlated with cumulative genetic events and with additional molecular abnormalities including mutation of cell oncogenes, inactivation of tumor suppressor genes (1-3), defects in DNA mismatch repair and aberrant DNA methylation (4-7).

Recently, aberrant expression of the proto-oncogene $c$-kit has been reported in a sub-group of colorectal carcinomas (CRC) (8-10). c-kit encodes a type III receptor tyrosine kinase, initially identified as the homologue of the Hardy-Zuckerman 4 feline sarcoma virus oncogene $(11,12)$. Triggering of the KIT receptor by its ligand stem cell factor (SCF) (13) exerts multiple effects, both during development and in adult life, supporting the survival, proliferation, migration, and homing of hematopoietic cells, mast cells, melanocyte precursors, and primordial germ cells (14).

Abnormal KIT expression has been observed in a variety of human tumors, including myeloid leukaemia $(15,16)$, melanoma $(17,18)$, glioblastoma (19), germ cell cancer $(20,21)$, breast cancer $(22,23)$ and small cell lung cancer $(24,25)$. Furthermore, gain-of-function mutations in $c$-kit have been described primarily in leukemias and gastrointestinal stromal tumors (GIST) (26). Two general mechanisms of $c$-kit activation in malignant cells have been described: acquisition of activating mutations or autocrine or paracrine stimulation of the receptor by its ligand SCF (27).

Previously, we (28) and others (29) have shown that SCF supports anchorage-independent growth, cell survival and migration/invasion of selected KIT-positive colon carcinoma cells in an autocrine/paracrine fashion. To assess the significance of these findings in the development of CRC, we decided to analyze mRNA expression patterns of SCF and c-kit and the relative in situ protein distribution at successive stages of CRC progression. 


\section{Materials and methods}

Tissue specimens and patients. The study group comprised 126 patients who were diagnosed either with colon adenoma $(n=32)$ or adenocarcinoma $(n=94)$ at the General Surgery Section of Department of Clinical Physiopathology (University of Turin, Turin, Italy) between January 1995 and June 2004. None underwent treatment before entering the study, which was conducted under strict observance of the principles of the Declaration of Helsinki. Adenoma tissue specimens were obtained through endoscopy and cancer specimens through surgical resection. All cancer patients had histopathologicallyconfirmed primary colorectal adenocarcinomas and were staged using the Dukes' system, as revised by Astler and Coller (30). Adenoma specimens were graded for degree of dysplasia (GD) ( $\mathrm{n}=10$ low, $\mathrm{L} ; \mathrm{n}=12$ moderate, $\mathrm{M} ; \mathrm{n}=10$ high, $\mathrm{H}$ ).

Histopathologically-confirmed normal colon biopsies $(n=73)$ were used as controls. Informed consent was obtained from patients for the experimental use of blood and surgical specimens, in accordance with the institutional ethics guidelines. The main clinical, demographic and pathological characteristics of the patients are shown in Tables I and II.

Aliquots of fresh normal, premalignant and malignant colon tissue were fixed in formalin and paraffin-embedded for immunohistochemical analysis or placed in liquid nitrogen prior to mRNA extraction. Frozen sections $(6-\mu \mathrm{m})$ were taken from blocks of tissue and, starting with the first section, every fifth section was routinely stained with hematoxylin and eosin and evaluated histopathologically by an experienced pathologist $(\mathrm{GV})$. Sections were pooled for $c$-kit and $S C F$ mRNA analysis from areas estimated to have at least $80 \%$ malignant cells. In the same way, colon mucosa specimens from patients free of neoplastic or inflammatory diseases were examined histopathologically and defined as 'normal' tissue.

Complete follow-up data were available for all patients. Among patients with polyps, the median follow-up of surviving patients was 44 months (range, 35-96 months). When the study was concluded, 5 (16\%) patients had died of causes nonattributable to the primary disease. Among cancer patients, $69(73 \%)$ were still alive, whereas $25(27 \%)$ had died [19/25 $(76 \%)$ from causes attributable to the primary disease]. The median follow-up period of surviving patients was 58 months (range, 8-102 months): 43 patients remained disease-free, whereas 26 had a recurrence. The median time to recurrence was 13.6 months (range, 3-60 months).

RNA extraction and reverse transcription. RNA was extracted from frozen tissue specimens, and from appropriate positive controls consisting of DLD-1 and M07 cell lines, using TRIzol reagent (Invitrogen, Life Technologies, Gaithersburg MD) following the manufacturer's instructions. To remove traces of genomic DNA, total RNA $(1 \mu \mathrm{g})$ was treated with DNase I (Invitrogen) and reverse-transcribed to cDNA using SuperScript II (Invitrogen) as described elsewhere (31).

Real-time reverse transcriptase ( $R T)$ - $P C R$. Real-time quantitative RT-PCR analysis was performed on the iCycler iQ system (Bio-Rad, Hercules, CA) with SYBR-Green I dye detection. Amplification of $18 \mathrm{~S}, c$-kit and SCF was performed
Table I. Main clinical and demographic features of the studied population.

\begin{tabular}{llll}
\hline & Controls & $\begin{array}{c}\text { Adenoma } \\
\text { patients }\end{array}$ & $\begin{array}{c}\text { Carcinoma } \\
\text { patients }\end{array}$ \\
\hline $\mathrm{n}$ & $73(37 \%)$ & $32(16 \%)$ & $94(47 \%)$ \\
Male & $35(48 \%)$ & $21(66 \%)$ & $48(51 \%)$ \\
Age, years & $52(25-85)$ & $63(44-78)$ & $63(31-87)$ \\
\hline
\end{tabular}

Data are presented as medians (range) for continuous variables, and as frequencies $(\%)$ for categorical variables.

in duplicate on a PCR optical 96-well reaction plate (BioRad). PCR mixture $(25 \mu \mathrm{l})$ in each well contained $5 \mu \mathrm{l}$ of cDNA (corresponding to $100 \mathrm{ng}$ of total RNA), $2.5 \mu \mathrm{l}$ of each sequence-specific primer (300 nM for rRNA $18 S$, c-kit, $S C F-1$ and $S C F-2), 12.5 \mu 1$ of $1 \mathrm{X}$ iQ SYBR-Green Supermix (Bio-Rad) and $2.5 \mu \mathrm{l}$ of nuclease-free water. Primer sequences were designed to be cDNA specific and to work under equivalent reaction conditions using Beacon Designer 2 Software (Bio-Rad); primers were synthesized by Invitrogen and reconstituted in nuclease-free water before use. The sequences of sense and antisense primers used for SCF were designed to detect transcripts corresponding to the transmembrane isoforms SCF-1 (long form) and SCF-2 (short form). Primer sequences and reaction efficiencies are listed in Table III. A negative PCR control without cDNA template and a positive control specimen with a known cycle threshold $\left(\mathrm{C}_{\mathrm{t}}\right)$ value were included in each assay. Optimized thermal cycling conditions were as follows: $5 \mathrm{~min}$ at $95^{\circ} \mathrm{C}$ followed by 40 cycles of $15 \mathrm{sec}$ at $95^{\circ} \mathrm{C}$ and $1 \mathrm{~min}$ at $60^{\circ} \mathrm{C}$ (two-step PCR). Specificity of the PCR products was confirmed by the melting curve program at the end of the reaction $\left(55-95^{\circ} \mathrm{C}\right.$ with a heating rate of $0.5^{\circ} \mathrm{C} / 10 \mathrm{sec}$ and continuous fluorescence measurements). PCR efficiency $(E)$ was determined using the iCycler iQ software and the method described by Ramakers et al (32). For each specimen the $\mathrm{C}_{\mathrm{t}}$ was acquired by the fit point method (33). The mRNA expression data for $18 \mathrm{~S}$ showed no significant differences between control and patient groups. The relative expression ratio of the target genes was computed using the Relative Expression Software Tool (REST) (34). This software calculates an expression ratio relative to the control group (normal colon tissue) normalized by a reference gene (rRNA 18S). The expression ratio (R) is: $\mathrm{R}=E_{\text {target }} \Delta \mathrm{Ct}$ target (mean control-mean specimen) $/ E_{\text {reference }} \Delta \mathrm{Ct}$ reference (mean control-mean specimen). An expression ratio of 1 means no regulation, $>1$ is up-regulation and $<1$ is down-regulation.

Immunohistochemical detection of $c-K I T$ and SCF. For immunohistochemistry, consecutive formalin-fixed, paraffinembedded tissue sections were immunostained for KIT, using a rabbit anti-KIT polyclonal antibody (Dako, Carpinteria, CA, USA, 1:100 dilution) which recognizes a peptide corresponding to amino acids 963-976 at the cytoplasmatic C-terminal portion, and for SCF, by means of an affinity-purified goat polyclonal antiserum raised against a peptide mapping at the 
Table II. Main pathological features of the studied population.

\begin{tabular}{|c|c|c|c|c|c|c|}
\hline Carcinoma Dukes' stages & $\mathrm{A}(\%)$ & B1 $(\%)$ & $\mathrm{B} 2(\%)$ & C1-C3 (\%) & $\mathrm{D}(\%)$ & Total $(\%)$ \\
\hline $\mathrm{n}$ & $15(16)$ & $13(14)$ & $25(27)$ & $24(25)$ & $17(18)$ & $94(100)$ \\
\hline \multicolumn{7}{|l|}{ Grading } \\
\hline $\mathrm{G} 1$ & 3 & 1 & 1 & 0 & 0 & $5(6)$ \\
\hline $\mathrm{G} 2$ & 9 & 10 & 21 & 17 & 11 & $68(72)$ \\
\hline G3 & 3 & 2 & 3 & 7 & 6 & $21(22)$ \\
\hline \multicolumn{7}{|l|}{ Tumor site } \\
\hline Right colon & 4 & 6 & 10 & 6 & 7 & $33(35)$ \\
\hline Transverse colon & 0 & 1 & 2 & 1 & 0 & $4(4)$ \\
\hline \multicolumn{7}{|l|}{ Descending and } \\
\hline Sigmoid colon & 8 & 3 & 11 & 12 & 5 & $39(42)$ \\
\hline Rectum & 3 & 3 & 2 & 5 & 5 & $18(19)$ \\
\hline
\end{tabular}

Data are presented as medians (range) for continuous variables, and as frequencies (\%) for categorical variables.

Table III. Primer sequences for cytokine quantification by real-time RT-PCR.

\begin{tabular}{|c|c|c|c|}
\hline Primer set & $\begin{array}{c}\text { GenBank } \\
\text { Accession no. }\end{array}$ & $\begin{array}{l}\text { Primer sequence } \\
\qquad\left(5^{\prime} \rightarrow 3^{\prime}\right)\end{array}$ & $\begin{array}{c}\text { RT-PCR } \\
E(\%)\end{array}$ \\
\hline $18 \mathrm{~S}$ sense & X03205 & CTGCCCTATCAACTTTCGATGGTAG & 1.99 \\
\hline $18 \mathrm{~S}$ antisense & & CCGTTTCTCAGGCTCCСТCTC & \\
\hline c-kit sense & X06182 & GATTATCCCAAGTCTGAGAATGAA & 1.97 \\
\hline c-kit antisense & & CGTCAGAATTGGACACTAGGA & \\
\hline SCF-1 sense & NM_000899 & CAGAGTCAGTGTCACAAAACCATT & 1.98 \\
\hline SCF-1 antisense & & TTGGCCTTCCTATTACTGCTACTG & \\
\hline SCF-2 sense & NM_003994 & CTGAGAAAGGGAAGGCCAAA & 2.02 \\
\hline SCF-2 antisense & & GCTGTCTCTTCTTCCAGTATAAG & \\
\hline
\end{tabular}

$\mathrm{E}=E=$ Efficiency deducted from the slope (s) of the standard curve based on $\mathrm{E}=\mathrm{e}^{\ln 10 / \mathrm{s}}-1$.

N-terminus (Santa Cruz Biotechnology, Santa Cruz, CA, USA; 1:100 dilution). The latter antibody does not discriminate between SCF-1 and SCF-2 isoforms. To detect the presence of mast cells, mouse anti-tryptase (Chemicom International, Temecula, CA; 1:1000 dilution) was used. Tissue sections were deparaffinized and rehydrated. Heat-induced epitope retrieval was performed with Target Retrieval Solution (Dako) using an electric pressure-cooker for $20 \mathrm{~min}$ at $120^{\circ} \mathrm{C}$, with cooling before immunostaining. All tissues were then exposed to $3 \%$ hydrogen peroxide for $5 \mathrm{~min}$, to quench endogenous peroxidase activity, and to primary antibody for $1 \mathrm{~h}$. Immunostaining for both proteins was then performed with the peroxidase-based visualization LSAB ${ }^{\circledR}$ kit (Dako), following the manufacturer's recommendations. Diaminobenzidine tetrahydrochloride was used as chromogen. Incubation was at room temperature; between incubations sections were washed with
Tris-buffered saline buffer. The slides were then counterstained with Mayer hematoxylin for $5 \mathrm{sec}$, dehydrated and mounted in Clarion (Biomeda, Foster City, CA, USA). A KIT-positive GIST tumor of the ileum and chorial villi were used as external positive controls for KIT and SCF expression, respectively $(35,36)$. Substitution of the primary antibody with normal rabbit or goat serum served as a negative control for all immunostaining tests. Specific staining for KIT and SCF, defined as the presence of stain in the plasma membrane and/or cytoplasm, was evaluated in the epithelial compartment. Internal controls for KIT immunostaining were inflammatory cells and interstitial cells of Cajal. Inflammatory cells were also considered as internal controls for SCF. Immunostaining was scored by the immunoreactive score (IRS) system proposed by Remmele and Stegner (37) in which IRS = SI (staining intensity) x PP (percentage of positive cells). SI was classified 
Table IV. Normalized mRNA expression patterns in colon adenoma and carcinoma specimens.

\begin{tabular}{lcccccc}
\hline mRNA expression & LGD $^{\mathrm{a}}$ & MGD $^{\mathrm{a}}$ & $\mathrm{HGD}^{\mathrm{a}}$ & $\mathrm{A}^{\mathrm{b}}$ & $\mathrm{B} 1 / \mathrm{B}^{\mathrm{b}}$ & $\mathrm{C}^{\mathrm{b}}$ \\
\hline kit & & & & & & \\
Up-regulation & $9 / 10(90)$ & $10 / 12(83)$ & $9 / 10(90)$ & & $23 / 38(61)$ & $28 / 41(68)$ \\
$\quad$ Down-regulation & $1 / 10(10)$ & $2 / 12(17)$ & $1 / 10(10)$ & $15 / 15(100)$ & $15 / 38(39)$ & $13 / 41(32)$ \\
SCF-1 & & & & & & \\
Up-regulation & $5 / 10(50)$ & $5 / 12(42)$ & $4 / 10(40)$ & $8 / 15(53)$ & $33 / 38(87)$ & $27 / 41(66)$ \\
Down-regulation & $5 / 10(50)$ & $7 / 12(58)$ & $6 / 10(60)$ & $7 / 15(47)$ & $5 / 38(13)$ & $14 / 41(34)$ \\
SCF-2 & & & & & & \\
$\quad$ Up-regulation & $7 / 10(70)$ & $9 / 12(75)$ & $10 / 10(100)$ & $14 / 15(93)$ & $32 / 38(84)$ & $27 / 41(66)$ \\
Down-regulation & $3 / 10(30)$ & $3 / 12(25)$ & & $1 / 15(7)$ & $6 / 38(16)$ & $14 / 41(34)$ \\
\hline
\end{tabular}

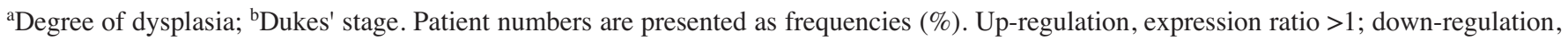
expression ratio $<1$.

as 0 , negative; 1 , weak; 2 , moderate; and 3 , strong. PP was defined as 0 , negative; $1,1-20 \%$ positive cells; $2,21-50 \%$ positive cells; and 3,51-100\% positive cells. Ten visual fields from different areas of each specimen were chosen at random for IRS evaluation, and the average IRS was calculated.

Determination of SCF concentrations in sera. SCF concentrations were determined using an ELISA kit (R\&D Systems, Abingdon, UK) in serum specimens from control subjects, adenoma and cancer patients, following the manufacturer's instructions. All specimens were evaluated in duplicate. The minimum detectable dose was below $9.0 \mathrm{pg} / \mathrm{ml}$.

Statistical analysis. Statistical data analysis was performed with the biomedical statistical software package BMDP Dynamic, Rel. 7.0 (Statistical Solutions, Cork, Ireland) and MedCalc, version 7.6.0.0 (Med-Calc Software, Mariakerke, Belgium). The compatibility of data from continuous variables with a normal distribution was checked by means of Shapiro and Wilk's W-test. Means and SDs are given throughout as measures of central tendency and dispersion for data with normal distribution, medians and range otherwise. Differences between continuous variables were analyzed by the Student's t-test or One-way analysis of variance when data were normally distributed, and by means of the Mann-Whitney or the KruskalWallis test otherwise. Associations between categorical variables were explored by means of Fisher's exact test and, when appropriate, the $\chi^{2}$ test for linear trend. Correlation between mRNA expression (determined by real-time PCR) and protein expression (by IHC), as well as between the IHC patterns of c-kit and SCF, were quantified in terms of the corresponding Spearman correlation coefficients. Survival data for patients still alive at the end of the study were calculated to the time of the last follow-up examination. The log-rank (Mantel-Cox) test was used to test the null hypothesis of similarity of survival times among patients with different IHC patterns. The statistical significance of differences in mRNA expression of the cytokines examined in patients and control groups was analyzed by the REST software package for group- wise comparison, and this was also used for statistical analysis of relative expression results in real-time PCR (34). A level of 0.05 (two-tailed) was chosen to indicate statistical significance.

\section{Results}

Expression of c-kit mRNA and protein in normal, dysplastic and malignant colorectal tissues. Quantitative RT-PCR showed that, in comparison to normal colon mucosa, in almost all adenomas kit message was overexpressed (expression ratio $>1$ ). In locally extended tumors (Dukes' stage A) kit mRNA was down-regulated (expression ratio $<1$ ), while in more advanced tumors kit message was upregulated (Table IV). Moreover, in general, $c$-kit mRNA was expressed at lower levels in cancer specimens than in adenomas (median ratio 1.236, range 0.119-32.806; ratio 4.180, range 0.120-29.807, respectively; $\mathrm{p}=0.001$ by the Mann-Whitney test). Nevertheless, when cancer patients were divided into the following three categories: Dukes' stages A, B1 or B2, C or D, a progressively increasing $c$-kit mRNA expression was observed (median ratio 0.473, range 0.371-0.791; ratio 1.249, range 0.119-29.807; and ratio 1.964 , range $0.196-32.806$, respectively; KruskalWallis test $=15.14, \mathrm{p}=0.0005$ ). By contrast, different degrees of dysplasia were not associated with significant variations in c-kit mRNA expression ( $\mathrm{p}=0.66)$.

Moderate $(3<\mathrm{IRS} \leq 6)$ in situ cytoplasmic KIT protein expression was observed in 10/94 (10.6\%) tumor specimens. In adenoma tissues, weak KIT immunostaining ( $1 \leq \mathrm{IRS} \leq 3)$ was observed only in $4 / 32(12.5 \%)$ of specimens, while it was virtually absent in epithelial cells of normal specimens. KIT was detected in the cytoplasm and/or on the cell membrane of inflammatory cells. When specimens were ordered in the following four categories: normal colon tissue, polyp, locally-advanced tumor (Dukes' stages A, B1 and B2), nodal or distally-spread tumor (Dukes' stages C and D), a strong linear trend for progressively higher KIT expression emerged ( $\chi^{2}$ for trend $=17.36, \mathrm{p}<0.0001$ ). Representative KIT immunostaining in normal, and in positive dysplastic and malignant colorectal tissues is shown in Fig. 1. 

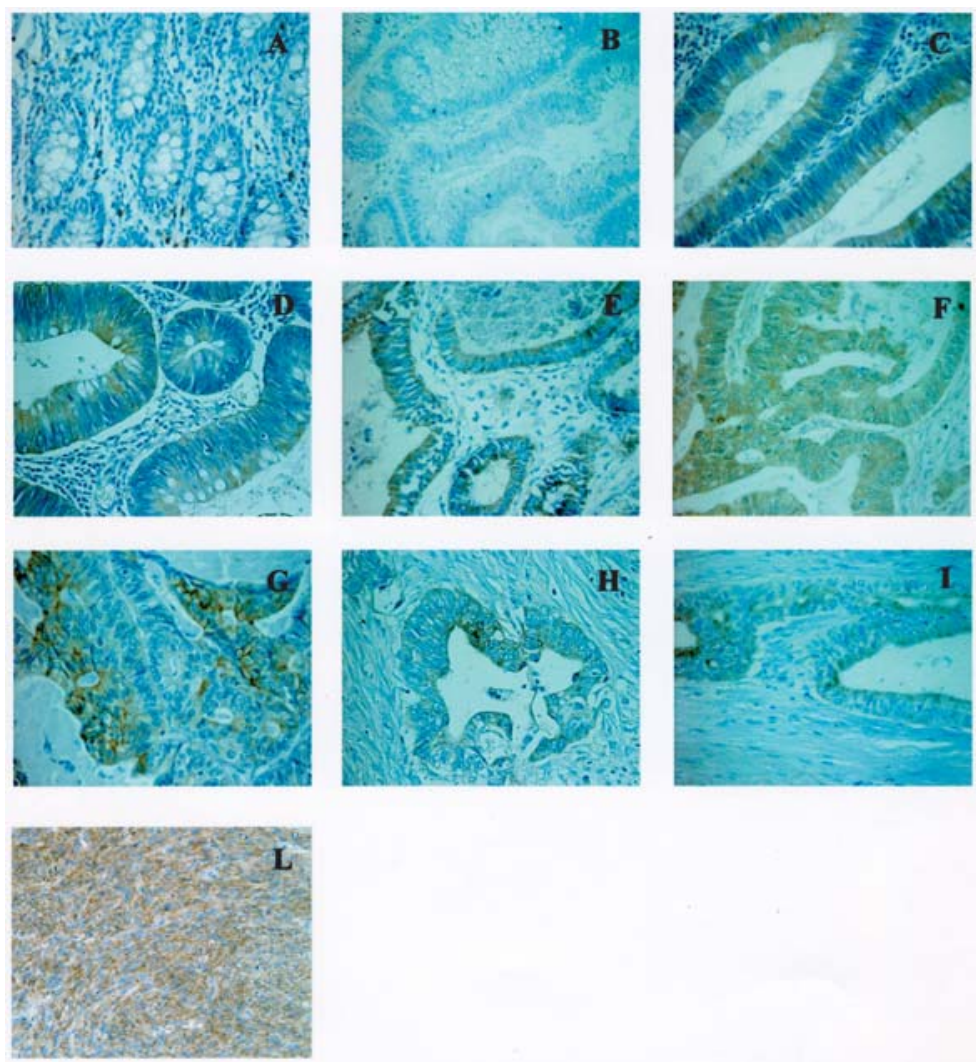

Figure 1. Representative immunohistochemical analysis of KIT protein expression in normal (A, negative staining), premalignant [degrees of dysplasia: low (B, negative staining), moderate (C, positive staining), and high (D, positive staining)] and malignant [Dukes' stages A (E, positive staining), B1 (F, positive staining), B2 (G, positive staining), C (H, positive staining), and D (I, positive staining)] colonic mucosa. L is the positive external control (human ileal GIST). (Original magnification x250).
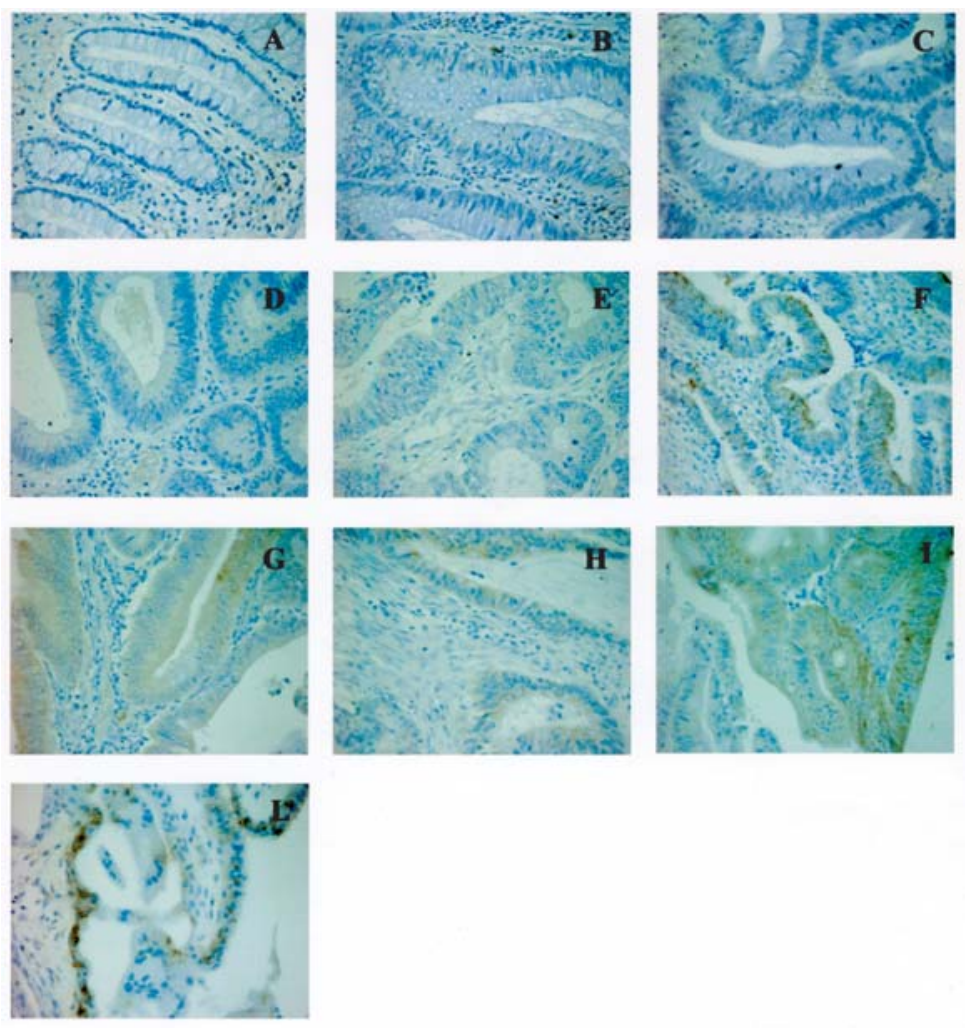

Figure 2. Representative immunohistochemical analysis of SCF protein expression in normal (A, negative staining), dysplastic [degrees of dysplasia: low (B, negative staining), moderate (C, negative staining), and high (D, negative staining)] and malignant [Dukes' stages A (E, negative staining), B1 (F, positive staining), B2 (G, positive staining), C (H, positive staining), and D (I, positive staining)] colorectal tissues. L is the positive external control (human placenta). (Original magnification $\times 250)$. 
Expression of SCF $m R N A$ and protein in normal, dysplastic and malignant colorectal tissues. We assessed SCF transcript levels quantitatively by means of real-time RT-PCR. Relative to normal mucosa samples, a slight majority of adenoma cases revealed relatively lower $S C F-1$ mRNA levels. In tumors, $S C F-1$ mRNA was generally higher, with the highest levels observed in more advanced forms (Table IV). In general, SCF-1 mRNA was expressed in cancer specimens at significantly higher levels than in adenomas (median relative expression 2.05, range 0.07-34.19; and median relative expression 0.60 , range $0.07-8.09$, respectively; $\mathrm{p}=0.007$ by the Mann-Whitney test). When cancers specimens were subdivided into the following three categories: Dukes' stages A, B1 or B2, C or D, significantly increased $S C F-1 \mathrm{mRNA}$ expression was observed in more advanced cases compared to the locally-advanced ones (respectively, medians of 1.03, 3.04 and 2.72; $\mathrm{p}=0.0003$ by the Kruskal-Wallis test).

By contrast, compared with normal colon mucosa, $S C F-2$ message was overexpressed in both, adenoma and the majority of carcinoma samples (Table IV). In general, cancer and adenoma specimens had similar $S C F-2$ mRNA relative expression values (median 2.20, range 0.15-30.72; and 2.15, $0.20-27.82$, respectively; $\mathrm{p}=0.33$ by the Mann-Whitney test). Moreover, Dukes' stage and degree of dysplasia did not affect $S C F-2$ mRNA expression in cancer and polyp specimens, respectively.

In situ protein expression for SCF was observed in 69/94 $(73.4 \%)$ cancer specimens and in $8 / 32$ (25\%) adenoma specimens; all control specimens were negative for SCF immunostaining; in these cases staining was confined to the cytoplasm of the occasionally-present mononuclear inflammatory cells. Moreover, only cancer specimens possessed an IRS $>1 \quad(\mathrm{p}<0.0001$ by Fisher's exact test $)$. When cancer specimens were ordered in four categories, Dukes' stages A, $\mathrm{B} 1, \mathrm{~B} 2$, and $\mathrm{C}$ or $\mathrm{D}$, the trend toward progressively increased $\mathrm{SCF}$ staining was very strong $\left(\chi^{2}\right.$ for trend $\left.=53.32, \mathrm{p}<0.0001\right)$. Representative SCF immunostaining in normal, dysplastic and malignant colorectal tissues is shown in Fig. 2 .

No significant statistical correlation was found between SCF-2 real-time RT-PCR expression ratios and immunohistochemistry scores. On the contrary, a strong correlation existed between these two methods with regard to SCF-1 $(R=0.401, \mathrm{p}<0.0001)$.

KIT and SCF protein co-expression. No co-expression of KIT and SCF proteins was observed in adenomas. By contrast, in malignant tumors, $8 / 10(80 \%)$ of KIT-positive cases also strongly expressed SCF. The $20 \%$ of KIT-positive cases that did not co-express both proteins were all locally-advanced carcinomas (Dukes A and B1).

KIT and SCF immunostaining scores and clinical course. No significant association was found between KIT protein expression and survival (Mantel-Cox $=2.013, \mathrm{p}=0.15$ ) or disease recurrence (Mantel-Cox $=1.706, \mathrm{p}=0.19$ ), after stratification for possible confounding variables such as gender or age. Similarly, no association was found between SCF immunohistochemical scores and survival (Mantel-Cox $=0.261, \mathrm{p}=0.60$ ) or disease recurrence (Mantel-Cox $=0.384$, $\mathrm{p}=0.53$ ), after allowing for the same confounding variables.
An association was found between KIT and SCF protein coexpression and survival (Mantel-Cox $=4.462, \mathrm{p}=0.04$ ) or recurrence (Mantel-Cox $=9.783, \mathrm{p}=0.01$ ), after stratification for the same possible confounding variables.

SCF levels in control and patients sera. Mean serum SCF concentrations were $1008 \pm 196 \mathrm{pg} / \mathrm{ml}, 1035 \pm 207 \mathrm{pg} / \mathrm{ml}$ and $961 \pm 190 \mathrm{pg} / \mathrm{ml}$, in controls, adenoma and cancer patients, respectively (One-way ANOVA, $\mathrm{p}=0.07$ ). Serum SCF concentrations were not affected by cancer stage or degree of dysplasia.

\section{Discussion}

Several reports have indicated that KIT tyrosine kinase is rarely detected in situ in CRC. Reed et al, using stage-oriented human cancer tissue microarrays, reported that in situ KIT expression is sparse in colorectal carcinomas with only $1.6 \%$ of positive tumors, being poorly-differentiated carcinomas arising at the anorectal junction (9). In another study, faint cytoplasmic KIT positivity was found in $4.8 \%$ of CRC cases (8). More recently, Sammarco et al detected KIT-positive staining in the epithelium of the neoplastic colon in $25 \%$ of patients examined (10). In a previous preliminary analysis conducted on a small number of patients, we reported KIT immunoreactivity in several malignant mucosa specimens compared to normal counterparts (38). The present evaluation of KIT expression using a polyclonal antibody recommended for accurate GIST diagnosis (39) and using a larger number of CRC cases at different disease stages as well as adenomas, confirms that KIT overexpression is rare in these tumor forms. In premalignant disorders and tumor specimens, respectively, we found weak and moderate KIT immunostaining only in 12.5 and $10.6 \%$. Nevertheless, when colon specimens were ordered by disease progression, a strong linear trend for progressively higher KIT expression emerged.

The discrepancy compared to our preliminary results may arise from the use of different reagents. Unfortunately, the quality of the earliest polyclonal anti-KIT antibodies produced and made available commercially was not very satisfactory, and different studies using a wide variety of different KIT antibodies, protocols, and scoring systems to identify KITpositive tumors often yielded discrepant results (40).

Interestingly, unlike the immunohistochemistry expression pattern, when $c$-kit mRNA levels were quantitatively examined in total tissue by real-time PCR, expression was lower in $\mathrm{CRC}$ than in adenoma or normal mucosa. Alongside the technical issues related to the sensitivities of the two techniques, a possible explanation for this reduced expression could relate to the immunohistochemical localization of the KIT protein in non-epithelial cells. Immunohistochemistry performed on consecutive sections of a limited number of the tissue specimens analyzed showed the mononuclear inflammatory cells expressing KIT to be mostly tryptasepositive mast cells (data not shown). A cell count determined the mean number of mast cells, due to extension of the neoplastic epithelium compartment in patients' tumor tissue specimens, to be significantly fewer in cancer specimens than in premalignant polyps or normal tissue sections. Similar decreased $c$-kit expression in the progression from normal 
colon to cancer has also been reported by another group, using standard RT-PCR (10). However, unlike in this study, we did not find a complete absence of $c$-kit mRNA in any of the tissue specimens examined.

The present study examined, for the first time, expression of the KIT ligand in normal, premalignant and malignant colon tissues. SCF immunoreactivity was not detected in normal control mucosa specimens; it was detected at a very low level in a few adenoma tissue specimens and in most cancer specimens, with a positive significant trend for progressive increase. Similar to c-kit expression, different expression patterns were observed for SCF when mRNA and protein abundance were compared in colorectal mucosa specimens by quantitative realtime RT-PCR and immunohistochemistry. SCF is produced by many cell types including mast cells (41), fibroblasts, stromal cells (42), and endothelial cells (43). The relative content of these cells and of epithelial cells may be altered in adenomatous and neoplastic tissues compared to normal tissues.

Moreover, two alternatively-spliced forms of membranebound $\mathrm{SCF}$, a larger form of $45 \mathrm{kDa}(\mathrm{SCF}-1)$ and a smaller form of $31 \mathrm{kDa}(\mathrm{SCF}-2)$ exist, both equally biologically active (44). The antibody used to detect SCF recognizes both membrane-bound long and short forms as well as soluble $\mathrm{SCF}$, while analysis at the mRNA level used two specific primers for SCF-1 and SCF-2 forms.

The discrepancy between SCF and c-kit mRNA and protein expression levels observed might also reflect distinct rates of receptor-mediated regulation and protein turnover in benign and malignant lesions, as discussed in more detail below.

We observed that normal and malignant mucosa specimens contained two SCF transcripts most likely generated by differential splicing of the $S C F$ message and encoding functionallydistinct isoforms of this cytokine. These two isoforms are distinguished by the presence (SCF-1) or absence (SCF-2) of exon 6 sequences which encode an amino acid sequence required for efficient cleavage of soluble SCF from its transmembrane precursor (44). Because the major proteolytic cleavage site is absent in SCF-2, it remains cell-associated to a greater degree than SCF-1 (44). Importantly, we observed variations in the ratio of steady-state transcript levels corresponding to $S C F-1$ and $S C F-2 \mathrm{mRNA}$ in benign and malignant lesions. After normalizing to controls, $S C F-1$ mRNA was found to be expressed in cancer specimens at significantly higher levels than in adenomas, and a significantly increased $S C F-1$ mRNA expression was observed in more advanced cases compared to locally-advanced ones. By contrast, cancer and adenoma specimens had a similar $S C F-2$ mRNA relative expression and Dukes' stage and degree of dysplasia did not affect $S C F-2$ mRNA expression in cancer and polyp specimens, respectively.

The distinct patterns of SCF isoform expression may have functional consequences related to the dynamics of ligandinduced receptor activation and turnover. Studies in SCF negative cells established from $S l / S l$ homozygous murine embryo fetal liver, and engineered to produce either soluble or transmembrane SCF, give support to this idea (45). Both SCF isoforms thus produced equally activated KIT on M07e cells. However, cell-associated SCF-1 induced sustained KIT phosphorylation, contrasted with transient phosphorylation of KIT induced by soluble SCF-2. Importantly, soluble but not cell-associated KIT rapidly down-regulated KIT expression and accelerated KIT protein degradation. Moreover, soluble recombinant human SCF added to cells expressing cellassociated SCF also markedly reduced cell-surface KIT expression and induced KIT protein degradation. Several lines of evidence suggest that preferential expression of either the long or the short form of SCF has consequences beyond receptor trafficking and dynamics. For example, mice expressing soluble SCF but lacking transmembrane SCF have a severe phenotype affecting SCF-dependent cell lineages (46). Conversely, mice producing SCF-2 only reveal increased sensitivity to sublethal doses of $\gamma$-irradiation (47). Furthermore, transmembrane SCF is more potent than soluble SCF in maintaining the survival of multipotent hemopoietic stem cells in vitro (48). Experiments in $S l / S l^{d}$ mouse embryos (48-50) have shown that, while transmembrane SCF plays a critical role in the proliferative response of primordial germ cells, soluble SCF is able to sustain cell migration but not cell proliferation.

Co-expression of KIT and SCF has been reported in several non-hematological malignancies including gynecological tumors $(51)$, small cell lung cancers $(25,52)$ and testicular tumors (53). Simultaneous expression of KIT and its ligand SCF has been reported in colon carcinoma cell lines $(54,55)$, in which a growth/survival/migration stimulating autocrine loop has been demonstrated $(28,29)$. In vitro studies indicated that KIT activation by autocrine or paracrine SCF is not a necessary requirement for colon carcinoma cell survival and growth in anchorage-independent conditions, although it can significantly amplify these malignant traits (28). The present study describes in vivo co-expression of SCF in $80 \%$ of KIT positive primary CRCs, all at more advanced tumor stages (Dukes' C and D). These results are consistent with the hypothesis that a KIT-dependent autocrine loop is established in a small number of nodal or distally-spread colorectal neoplasias. However, at present, the biological significance of this coexpression in colon carcinogenesis remains unclear.

It is noteworthy that our previous study showed that three primary cell lines derived from Dukes' D carcinomas, expressing SCF mRNA, but negative or weakly positive for KIT in immunohistochemistry, in culture expressed KIT at both mRNA and protein levels (56). The discrepancy between observations on paraffin-embedded tissue and primary cell lines might be explained by the assumption that the kit gene may be somehow up-regulated in colon carcinoma cells during in vitro cell maintenance.

Unlike in other tumors $(57,58)$, the clinical impact of deregulated expression of this ligand/receptor system in CRC remains, at least in part, controversial. As a matter of fact, when KIT or SCF protein expression was analyzed separately, no significant association was found between either patient survival or disease recurrence. This unexpected result may be influenced by the very low incidence of CRCs aberrantly expressing $c$-kit, or it may be explained by the minor role played by KIT/SCF-dependent loop in the pathogenesis of this neoplasm. However, when KIT and SCF co-expression was taken into account, a negative prognostic value for both survival and cancer recurrence was found.

From the standpoint of medical treatment, CRC has been considered for decades a single-drug cancer type, since 
5-fluorouracil (FU)-based palliative chemotherapy was the only choice. During the past five years the use of several cytotoxic drugs, sometimes in combination, has provided significant benefit to the patients, particularly in the metastatic setting (59). An additional increase in the effectiveness of systemic therapies can be expected from the new group of drugs targeting specific cellular pathways, such as tyrosine kinase inhibitor imatinib mesylate (STI-571, Gleevec ${ }^{\circledR}$ ) (60). STI-571 has been used with interesting results to treat GIST (61). Although the above considerations suggest that KIT is not an attractive target in the majority of CRCs, it is possible that inhibition of KIT kinase activity might make colon carcinoma cells more susceptible to targeting another pathway. Our previous findings in vitro demonstrating that, in DLD-1 cells, STI-571 enhances the cytotoxic activity of 5-FU (56), support the clinical attractiveness of STI-571 in combination with conventional anticancer agents for a selected group of CRC patients, not responding to conventional therapies. The lesson learned from clinical trials of imatinib in GIST is that the mutational status of $c$-kit is required to achieve a successful response and improve survival (62). The presence of a truncated $c$-kit form with potentially strong activation capacity has been reported in some colon carcinoma cell lines $(54,63)$ and, at the moment, in a single CRC patient (10). However, since we detected SCF in the majority of KIT-positive CRCs, it is conceivable that, in this tumor, activation of the receptor may be supported by this autocrine circuit. Therefore, based on these findings, it is tempting to speculate that the subgroup of CRCs co-expressing KIT and SCF may have the potential to benefit the most from treatment with tyrosine kinase inhibitors.

\section{Acknowledgements}

We thank Dr Ulrich Rodeck for critical reading of the manuscript. This work was supported by grants from the Regione Piemonte to G.E and G.B and from the MIUR (ex-60\%) to G.E. A.B. is the recipient of an award from the Piedmontese Regional Government. T.S. is the recipient of an award from the Compagnia San Paolo, Turin, Italy.

\section{References}

1. Kinzler KW and Vogelstein B: Lessons from hereditary colorectal cancer. Cell 87: 159-170, 1996.

2. Kinzler KW and Vogelstein B: Cancer-susceptibility genes. Gatekeepers and caretakers. Nature 386: 761-763, 1997

3. Cho KR and Vogelstein B: Genetic alterations in the adenomacarcinoma sequence. Cancer 70: 1727-1731, 1992.

4. Eshleman JR and Markowitz SD: Microsatellite instability in inherited and sporadic neoplasms. Curr Opin Oncol 7: 83-89, 1995.

5. Marra G and Boland CR: Hereditary non-polyposis colorectal cancer: the syndrome, the genes, and historical perspectives. J Natl Cancer Inst 87: 1114-1125, 1995.

6. Kolodner R: Biochemistry and genetics of eukaryotic mismatch repair. Genes Dev 10: 1433-1442, 1996.

7. Myohanen SK, Baylin SB and Herman JG: Hypermethylation can selectively silence individual p16ink4A alleles in neoplasia. Cancer Res 58: 591-593, 1998.

8. Yorke R, Chirala M and Younes M: c-kit proto-oncogene product is rarely detected in colorectal adenocarcinoma. J Clin Oncol 21: 3885-3886, 2003.

9. Reed J, Ouban A, Schickor FK, Muraca P, Yeatman T and Coppola D: Immunohistochemical staining for c-Kit (CD117) is a rare event in human colorectal carcinoma. Clin Colorectal Cancer 2: 119-122, 2002.
10. Sammarco I, Capurso G, Coppola L, et al: Expression of the protooncogene c-KIT in normal and tumor tissues from colorectal carcinoma patients. Int J Colorectal Dis 19: 545-553, 2004.

11. Yarden Y, Kuang WJ, Yang-Feng T, et al: Human protooncogene c-kit: a new cell surface receptor tyrosine kinase for an unidentified ligand. EMBO J 6: 3341-3351, 1987.

12. Besmer P, Murphy JE, George PC, et al: A new acute transforming feline retrovirus and relationship of its oncogene v-kit with the protein kinase gene family. Nature 320: 415-421, 1986.

13. Anderson DM, Lyman SD, Baird A, et al: Molecular cloning of mast cell growth factor, a hematopoietin that is active in both membrane bound and soluble forms. Cell 63: 235-243, 1990.

14. Galli SJ, Zsebo KM and Geissler EN: The kit ligand, stem cell factor. Adv Immunol 55: 1-96, 1994

15. Wang C, Curtis JE, Geissler EN, McCulloch EA and Minden MD: The expression of the proto-oncogene C-kit in the blast cells of acute myeloblastic leukemia. Leukemia 3: 699-702, 1989.

16. Ikeda H, Kanakura Y, Tamaki T, et al: Expression and functional role of the proto-oncogene c-kit in acute myeloblastic leukemia cells. Blood 78: 2962-2968, 1991.

17. Natali PG, Nicotra, MR, Winkler AB, Cavaliere R, Bigotti A and Ullrich A: Progression of human cutaneous melanoma is associated with loss of expression of c-kit proto-oncogene receptor. Int J Cancer 52: 197-201, 1992.

18. Montone KT, van Belle P, Elenitsas R and Elder DE: Protooncogene c-kit expression in malignant melanoma: protein loss with tumor progression. Mod Pathol 10: 939-944, 1997.

19. Berdel WE, De Vos S, Maurer J, et al: Recombinant human stem cell factor stimulates growth of a human glioblastoma cell line expressing c-kit protooncogene. Cancer Res 52: 3498-3502, 1992.

20. Tian Q, Frierson HF Jr, Krystal GW and Moskaluk CA: Activating c-kit gene mutations in human germ cell tumors. Am J Pathol 154: 1643-1647, 1999.

21. Bokemeyer C, Kuczyk MA, Dunn T, et al: Expression of stemcell factor and its receptor c-kit protein in normal testicular tissue and malignant germ-cell tumours. J Cancer Res Clin Oncol 122: 301-306, 1996.

22. Natali PG, Nicotra MR, Sures I, Mottolese M, Botti C and Ullrich A: Breast cancer is associated with loss of the c-kit oncogene product. Int J Cancer 52: 713-717, 1992.

23. Hines SJ, Organ C, Kornstein MJ and Krystal GW: Coexpression of the c-kit and stem cell factor genes in breast carcinomas. Cell Growth Differ 6: 769-779, 1995.

24. Hida T, Ueda R, Sekido Y, et al: Ectopic expression of c-kit in small-cell lung cancer. Int J Cancer Suppl 8: 108-109, 1994.

25. Krystal GW, Hines SJ and Organ CP: Autocrine growth of small cell lung cancer mediated by coexpression of c-kit and stem cell factor. Cancer Res 56: 370-376, 1996.

26. Feng F, Liu XH, Xie Q, Liu WQ, Bai CG and Ma DL: Expression and mutation of c-kit gene in gastrointestinal stromal tumors. World J Gastroenterol 9: 2548-2451, 2003.

27. Vlahovic $\mathrm{G}$ and Crawford $\mathrm{J}$ : Activation of tyrosine kinases in cancer. Oncologist 8: 531-538, 2003.

28. Bellone G, Carbone A, Sibona N, et al: Aberrant activation of c-kit protects colon carcinoma cells against apoptosis and enhances their invasive potential. Cancer Res 61: 2200-2206, 2001

29. Attoub S, Rivat C, Rodrigues S, et al: The c-kit tyrosine kinase inhibitor STI571 for colorectal cancer therapy. Cancer Res 17: 4879-4883, 2002.

30. Astler VB and Coller FA: The prognostic significance of direct extension of carcinoma of the colon and rectum. Ann Surg 139: 846-852, 1954.

31. Carbone A, Rodeck U, Mauri FA, et al: Human pancreatic carcinoma cells secrete bioactive Interleukin-18 after treatment with 5-Fluorouracil: implications for anti-tumor immune response. Cancer Biol Ther 4: 231-241, 2005.

32. Ramakers C, Ruijter JM, Deprez RH and Moorman AF: Assumption-free analysis of quantitative real-time polymerase chain reaction (PCR) data. Neurosci Lett 339: 62-66, 2003.

33. Rasmussen R: Quantification on the LightCycler. In: Rapid Cycle Real-time PCR, Methods and Applications. Meuer S, Wittwer C and Nakagawara K (eds). Springer Press, Heidelberg, pp21-34, 2001.

34. Pfaffl MW, Horgan GW and Dempfle L: Relative expression software tool (REST) for group-wise comparison and statistical analysis of relative expression results in real-time PCR. Nucleic Acids Res 30: E36, 2002. 
35. Graadt van Roggen JF, van Velthuysen ML and Hogendoorn PC: The histopathological differential diagnosis of gastrointestinal stromal tumours. J Clin Pathol 54: 96-102, 2001.

36. Kauma S, Huff T, Krystal G, Ryan J, Takacs P and Turner T: The expression of stem cell factor and its receptor, c-kit in human endometrium and placental tissues during pregnancy. Clin Endocrinol Metab 81: 1261-1266, 1996.

37. Remmele W and Stegner HE: Recommendation for uniform definition of an immunoreactive score (IRS) for immunohistochemical estrogen receptor detection (ER-ICA) in breast cancer tissue. Pathologe 8: 138-140, 1987.

38. Bellone G, Silvestri S, Artusio E, et al: Growth stimulation of colorectal carcinoma cells via the c-kit receptor is inhibited by TGF-beta 1. J Cell Physiol 172: 1-11, 1997.

39. Hogendoorn PC, Joensuu H, Le Cesne A, et al: GIST consensus meeting panelists. Consensus meeting for the management of gastrointestinal stromal tumors. Report of the GIST Consensus Conference of 20-21 March 2004, under the auspices of ESMO. Ann Oncol 16: 566-578, 2005.

40. Miettinen M and Lasota J: KIT (CD117): a review on expression in normal and neoplastic tissues, and mutations and their clinicopathologic correlation. Appl Immunohistochem Mol Morphol 13: 205-220, 2005.

41. Zhang S, Anderson DF, Bradding P, et al: Human mast cells express stem cell factor. J Pathol 186: 59-66, 1998.

42. Heinrich MC, Dooley DC, Freed AC, et al: Constitutive expression of steel factor gene by human stromal cells. Blood 82: 771-783, 1993

43. Broudy VC, Kovach NL, Bennett LG, Lin N, Jacobsen FW and Kidd PG: Human umbilical vein endothelial cells display highaffinity c-kit receptors and produce a soluble form of the c-kit receptor. Blood 83: 2145-2152, 1994.

44. Huang EJ, Nocka KH, Buck J and Besmer P: Differential expression and processing of two cell-associated forms of the kit-ligand: KL-1 and KL-2. Mol Biol Cell 3: 349-362, 1992.

45. Miyazawa K, Williams DA, Gotoh A, Nishimaki J, Broxmeyer HE and Toyama K: Membrane-bound Steel factor induces more persistent tyrosine kinase activation and longer life span of c-kit gene-encoded protein than its soluble form. Blood 85: 641-649, 1995.

46. Russell ES: Hereditary anemias of the mouse: a review for geneticists. Adv Genet 20: 357-459, 1979.

47. Tajima Y, Moore MA, Soares V, Ono M, Kissel H and Besmer P: Consequences of exclusive expression in vivo of Kit-ligand lacking the major proteolytic cleavage site. Proc Natl Acad Sci USA 95: 11903-11908, 1998.

48. Williams DE, De Vries P, Namen AE, Widmer MB and Lyman SD: The Steel factor. Dev Biol 151: 368-376, 1992.
49. McCoshen JA and McCallion DJ: A study of the primordial germ cells during their migratory phase in Steel mutant mice. Experientia 31: 589-590, 1975.

50. Silvers WK: Dominant spotting, patch and rump white. In: The coat colors of mice: a model for gene action and interaction. Springer-Verlag, New York, pp206-332, 1979.

51. Inoue M, Kyo S, Fujita M, Enomoto T and Kondoh G: Coexpression of the c-kit receptor and the stem cell factor in gynecological tumors. Cancer Res 54: 3049-3053, 1994.

52. Hibi K, Takahashi T, Sekido Y, et al: Coexpression of the stem cell factor and the c-kit genes in small-cell lung cancer. Oncogene 6: 2291-2296, 1991.

53. Strohmeyer T, Reese D, Press M, Ackermann R, Hartmann M and Slamon D: Expression of the c-kit proto-oncogene and its ligand stem cell factor (SCF) in normal and malignant human testicular tissue. J Urol 153: 511-515, 1995.

54. Toyota M, Hinoda Y, Takaoka A, et al: Expression of c-kit and kit ligand in human colon carcinoma cells. Tumour Biol 14: 295-302, 1993.

55. Lahm H, Amstad P, Yilmaz A, et al: Interleukin 4 down-regulates expression of c-kit and autocrine stem cell factor in human colorectal carcinoma cells. Cell Growth Differ 6: 1111-1118, 1995.

56. Bellone G, Ferrero D, Carbone A, et al: Inhibition of cell survival and invasive potential of colorectal carcinoma cells by the tyrosine kinase inhibitor STI571. Cancer Biol Ther 3: 385-392, 2004.

57. Krams M, Parwaresch R, Sipos B, Heidorn K, Harms D and Rudolph P: Expression of the c-kit receptor characterizes a subset of neuroblastomas with favorable prognosis. Oncogene 23: 588-595, 2004.

58. Micke P, Basrai M, Faldum A, et al: Characterization of c-kit expression in small cell lung cancer: prognostic and therapeutic implications. Clin Cancer Res 9: 188-194, 2003.

59. Iqbal S and Lenz HJ: Integration of novel agents in the treatment of colorectal cancer. Cancer Chemother Pharmacol 54 (suppl 1): S32-S39, 2004.

60. Druker BJ: Imatinib as a paradigm of targeted therapies. Adv Cancer Res 91: 1-30, 2004.

61. Sawaki A and Yamao K: Imatinib mesylate acts in metastatic or unresectable gastrointestinal stromal tumor by targeting KIT receptors. Cancer Chemother Pharmacol 54 (suppl 1): S44-S49, 2004.

62. Demetri GD, von Mehren M, Blanke CD, et al: Efficacy and safety of imatinib mesylate in advanced gastrointestinal stromal tumors. N Engl J Med 347: 472-480, 2002.

63. Toyota M, Hinoda Y, Itoh F, Takaoka A, Imai K and Yachi A Complementary DNA cloning and characterization of truncated form of c-kit in human colon carcinoma cells. Cancer Res 54: 272-275, 1994. 